\title{
СИНТЕЗ И ПРОТИВОВОСПАЛИТЕЛЬНАЯ АКТИВНОСТЬ НОВЫХ ПРОИЗВОДНЫХ ИЗОПИМАРОВОЙ КИСЛОТЫ
}

\author{
М.А. Громова', Ю.В. Харитонов², С.А. Борисов², Э.Э. Шульц² \\ ${ }^{1}$ Новосибирский государственный педагогический университет, \\ 630126, Россия, Новосибирск, ул. Вилюйская, д.28. \\ ${ }^{2}$ Новосибирский институт органической химии им. Н.Н. Ворожцова СО РАН, \\ 630090, Россия, Новосибирск, просп. Академика Лаврентьева, д.9.
}

DOI: 10.19163/MedChemRussia2021-2021-38

E-mail: timoshenko_m_a@mail.ru

Изопимаровая кислота 1, доступный метаболит кедра сибирского Pinus sibirica, обладает широким спектром биологического действия, включая противовоспалительную активность [1]. В продолжении работ [2,3] по проведению селективных превращений изопимаровой кислоты были получены аналоги терпеноида, в которых карбоксильная группа удалена от терпенового остова на этильный 6а и пропильный 6d фрагменты.

Указанные целевые соединения получены в результате превращений, включающих синтез альдегидов 2 и 9, с последующим взаимодействием с карбанионом фосфиноксида, синтезированного in situ при депротонировании фосфоацетата 3 гидридом натрия, восстановление двойной связи в присутствии $\mathrm{Mg}$ в метаноле и щелочной гидролиз сложноэфирной группы. Гомолог карбальдегида изопимаровой кислоты 9 образуется в результате олефинирования альдегида 2 по Виттигу с использованием хлорида метоксиметил(трифенил)фосфония 7 и бутил лития с последующим кислотным гидролизом.


в докладе.

Противовирусная активность полученных соединений будет обсуждена

Исследование выполнено при финансовой поддержке РФФИ в рамках научного проекта № 19-33-60043.

\section{Литература}

[1] Смоляные кислоты хвойных России, Химия, фармакология / Толстиков, Г.А., Толстикова Т.Г., Шульц Э.Э. и др. - Н.: Гео, 2011. - 395 с.

[2] M.A. Gromova, Yu.V. Kharitonov, M.A. Pokrovskii, I.Yu. Bagryanskaya, A.G. Pokrovskii, E.E. Shults, Chem. Nat. Compd. 2019, 1, 47-53.

[3] M.A. Gromova, Yu.V. Kharitonov, I.Yu. Bagryanskaya, E.E. Shults, ChemistryOpen. 2018, 7, 890-901. 